\title{
(INTER)SUBJETIVIZAÇÃO DE MARCADORES DISCURSIVOS DE BASE VERBAL: INSTÂNCIAS DE GRAMATICALIZAÇÃO
}

\author{
Cláudia Andrea ROST SNICHELOTTO* \\ Edair Maria GÖRSKI ${ }^{* *}$
}

- RESUMO: Este artigo objetiva apresentar, numa perspectiva pancrônica, uma descrição da multifuncionalidade dos marcadores discursivos olha e vê ${ }^{1}$ em amostras de escrita e de fala catarinense. A análise é sustentada por uma abordagem funcionalista da gramaticalização, com ênfase na mudança semântico-pragmática e categorial dos itens, considerando a questão da (inter)subjetividade e (inter)subjetivização e sua relação com as funções da linguagem no processo de mudança. As ocorrências examinadas evidenciam que (i) das práticas comunicativas emergem polissemias pragmáticas, que sinalizam, em graus variáveis, o envolvimento do falante com o ouvinte, bem como um incremento de significados vinculados à atitude do falante a respeito do que é dito, além de tímida função dos itens no âmbito textual; (ii) os diferentes contextos de atuação discursiva de olha e vê são atestados a partir de frequências de uso que apontam tanto para situações de variação como para contextos de restrição de uso; (iii) há indícios de gramaticalização desses marcadores discursivos, estando olha num processo mais adiantado do que vê.

- PALAVRAS-CHAVE: Marcadores discursivos. Olha e vê. (Inter)subjetivização. Gramaticalização.

\section{Introdução ${ }^{2}$}

Neste $\operatorname{artigo}^{3}$ pretendemos (i) descrever o funcionamento dos marcadores discursivos (daqui em diante MDs - categoria definida na próxima seção) olha e vê em amostra escrita (peças teatrais de autores catarinenses dos séculos XIX e XX) e oral (dados do projeto VARSUL de Santa Catarina, da década de 1990),

* UFFS - Universidade Federal da Fronteira Sul. Chapecó - Santa Catarina - Brasil. 89802-112 - claudiarost@uffs. edu.br

** UFSC - Universidade Federal de Santa Catarina. Florianópolis - SC - Brasil. 88040-900 - gorski@cce.ufsc.br

1 Adotamos como representantes dos itens em estudo as formas olha e vê, negritadas. Embora essas formas apresentem realizações distintas para a primeira, olha olhe ['oja] ['oj] ['o], e para a segunda, vejas veja vê vês, inclusive construções como olha só e veja bem, escolhemos as derivadas do indicativo porque são as de uso mais generalizado nas entrevistas do Projeto Interinstitucional VARSUL (ROST, 2002; ROST SNICHELOTTO, 2009). Usaremos "olhar" e "ver" ao nos referirmos aos verbos.

2 Agradecemos as contribuições do parecerista anônimo. Quaisquer problemas remanescentes são de nossa responsabilidade.

3 Este artigo é uma retomada revista de parte da tese de Rost Snichelotto (2009). 
considerando etapas de mudança semântico-pragmática e categorial desses itens; e (ii) discutir esses processos de mudança como instâncias de gramaticalização. Nossa abordagem é prioritariamente discursiva/textual, considerando a interação entre os interlocutores nos eventos de fala e buscando depreender indícios de mudança a partir da observação do uso linguístico. A gramática é vista como rotinização e regularização de padrões de uso, codificando articuladamente os níveis da informação proposicional (semântica proposicional) e do discurso multiproposicional (pragmática discursiva) (GIVÓN, 2001).

Tomamos como suporte teórico as correlações entre trajetória de mudança e funções da linguagem (ideacional, interpessoal e textual) sugeridas por Traugott (1982, 1989, 2002, 2003a, 2003b, 2010), com ênfase no cline de (inter)subjetivização, e por Heine, Claudi e Hünnemeyer (1991), com ênfase na função interpessoal; bem como os parâmetros para identificar e descrever instâncias de gramaticalização propostos por Heine e Kuteva (2007).

A escolha por tal abordagem decorre da natureza do objeto analisado: MDs que derivam de atos de fala manipulativos expressos por meio de formas verbais com usos rotinizados em P2. ${ }^{4}$ A proposta de Traugott (1982, 1989, 2002, 2003a, 2010) a respeito da expansão de significados (inter)subjetivos pragmáticos a partir da intersubjetividade inerente ao contexto de P2, associada à ideia de Heine, Claudi e Hünnemeyer (1991) de que o desenvolvimento da função textual é posterior à interpessoal - expansões admitidas como instâncias de gramaticalização -, dá suporte à análise apresentada neste artigo. Ademais, a aplicação dos parâmetros sugeridos por Heine e Kuteva (2007) aos dados analisados, aliada ao controle da frequência de uso das formas em suas diferentes funções, nos termos de Bybee (2003), oferece elementos que auxiliam na avaliação do estágio de gramaticalização em que se encontram os MDs olha e vê no português.

Vários trabalhos levados a cabo com amostras diacrônicas do português se utilizam da proposta de Traugott (1982, 1995, 2003a) relativa ao cline de (inter) subjetivização para explicar as trajetórias de mudança dos itens/construções estudados. Longhin-Thomazi $(2003,2006)$, por exemplo, tratou da gramaticalização de só que e de ainda; Lopes-Damasio (2008) analisou a emergência e a multifuncionalidade do marcador discursivo assim. Esses trabalhos, entre outros, atestam a aplicabilidade da proposta da mudança de elementos de natureza adverbial que migram para a categoria de conector e/ou de marcador discursivo.

Vale ressaltar que, no caso do objeto analisado neste artigo, os MDs são originários de verbos e que, em geral, MDs como sabe?, entende?, tá?, olha, vê etc. não têm sido considerados como instâncias de gramaticalização (como ocorre

Os códigos P2 e P1 remetem, respectivamente, à segunda e à primeira pessoa do discurso (CAMARA JUNIOR., 1994). 
com MDs e/ou conectores oriundos de advérbios, como assim, então, lá etc.), mas de discursivização (MARTELOTTA; VOTRE; CEZARIO, 1996). Não é de nosso interesse polemizar essa questão aqui. Defendemos, contudo, - especialmente com base nas propostas teóricas de Traugott (1982, 1989, 2002, 2003b, 2010), nas análises de MDs de base verbal em outras línguas românicas, conforme veremos adiante, e nas evidências por nós encontradas no português - que é legítimo analisar também os MDs de base verbal sob a ótica da gramaticalização.

Para levar a cabo essa tarefa, organizamos o artigo em quatro seções, além da introdução e das considerações finais. Na sequência, apresentamos breve revisão da literatura sobre os MDs derivados de verbos de percepção, a qual ancora a identificação dos contextos de atuação discursiva dos MDs sob análise. As duas seções seguintes são destinadas, respectivamente, ao embasamento teórico e metodológico. Por fim, descrevemos rapidamente a mudança semânticopragmática e categorial dos itens em foco, detalhamos aspectos formais dos MDs e apresentamos a análise dos contextos de atuação discursiva de olha e vê nas amostras examinadas.

\section{Breve revisão da literatura sobre os MDs derivados de verbos de percepção}

O interesse pelo estudo dos MDs tem despontado em diferentes áreas da linguística, tanto no Brasil quanto no exterior. O que assinala a revisão da literatura ${ }^{5}$ sobre o assunto é que os MDs não se enquadram facilmente em uma classe formal de palavras devido à dificuldade de formação de um paradigma homogêneo, uma vez que provêm de um universo de categorias (conjunções, preposições, advérbios, verbos, além de expressões não verbais, estruturas sintáticas, fenômenos prosódicos etc.). Mais comum é a posição de considerálos como uma classe funcional (SCHIFFRIN, 1987; RISSO; SILVA; URBANO, 1996, 2006) a qual também adotamos neste trabalho. Consideramos que os MDs são elementos multifuncionais que "Amarram o texto não só enquanto estrutura verbal cognitiva, mas também enquanto estrutura de interação interpessoal" (URBANO, 1997, p.86). São itens que desempenham um papel comunicativo importante, podendo articular simultaneamente diferentes valores, com graus de maior ou menor proeminência, tanto de caráter textual - estabelecendo elos coesivos entre partes do texto, como interpessoal, mantendo a interação falante-ouvinte $(\mathrm{F}-\mathrm{O})^{6}$ e auxiliando no planejamento da fala (MARCUSCHI, 1989, p.282). Essa definição

\footnotetext{
Para uma revisão mais abrangente e detalhada acerca de diferentes enfoques e critérios definidores dos MDs, e de estudos sobre marcadores em português e demais línguas românicas, particularmente os de base verbal, remetemos o leitor ao trabalho de Rost Snichelotto (2009).

6 As letras F e O são usadas para referir os interlocutores: falante/escritor e ouvinte/leitor, respectivamente.
} 
ressalta a função pragmática da categoria, na qual se pode também incluir os MDs derivados de verbos de percepção olha e vê.

No Português Brasileiro, os MDs derivados de verbos de percepção, entre outros, têm sido investigados principalmente pelo grupo de pesquisadores vinculados ao projeto Gramática do Português Falado que atuam na perspectiva textual-interativa. A seguir, apresentamos breve apanhado de alguns desses trabalhos, e de outros que são relevantes para o tema em pauta neste artigo.

Risso, Silva e Urbano (1996) ${ }^{7}$ buscaram o estabelecimento de traços definidores do estatuto dos MDs identificados funcionalmente como basicamente orientadores da interação. Posteriormente, Urbano (1997, 1999, 2006) observou subfunções, propriedades e comportamentos interativos salientes de olha $\sim$ olhe, vamos ver, veja e viu?. Risso $(1999,2006)$ deteve-se na análise qualitativa das funções textuais dos MDs olha olhe $\sim$ ó, com centração nos aspectos da orientação interacional e da articulação de segmentos do texto. Travaglia (1999), por sua vez, levantou a hipótese de que alguns marcadores teriam a função de marcar relevo, o que seria feito sobretudo por aqueles que objetivam chamar a atenção para determinados elementos e ideias, como olhe, olha, ó, óia, veja e veja bem. Mais recentemente, Guerra (2007) descreveu MDs de base verbal, entre os quais olha e viu, como exercendo majoritariamente funções predominantemente interacionais.

No âmbito das demais línguas românicas, observa-se que, tal como em PB, a depender do contexto, verbos de percepção visual migram de categoria para atuar como MDs, situação em que funcionariam como elementos de chamamento da atenção do O para um aspecto do texto do F. Citem-se, por exemplo, as formas espanholas mira e ¿ves? investigadas por Pons Bordería (1998), Cuenca e Marin (2000), Galué (2002) e Domínguez e Alvarez (2005); a forma francesa regarde, pesquisada por Dostie (1998); o equivalente italiano guarda, investigado por Waltereit (2002); as formas catalãs a veure e miri, pesquisadas por Marin Jordá (2003); e as galegas olla e mira, investigadas por Domínguez Portela (2008). Além da base verbal comum entre essas línguas, convém ressaltar ainda que Cuenca e Marin (2000), ancoradas em Hopper e Traugott (2003a), analisam as formas mira e ¿ves? como um processo de gramaticalização relacionado à subjetivização, com uma pragmatização do significado derivada da forma fonte; Galué (2002) identifica mira/mire como formas gramaticalizadas que funcionam como MDs; Waltereit (2002) fundamenta em Traugott e König (1991) o movimento de mudança semântica de guarda, envolvendo convencionalização de implicaturas

Anteriormente, Castilho (1989) apresentou a caracterização formal e funcional dos MDs olha e veja bem; Marcuschi (1989) analisou as formas, posições e funções dos Marcadores Conversacionais como olha olhe e viu?. Também Martelotta, Votre e Cezario (1996), do Grupo Discurso \& Gramática, e Silva e Macedo (1996), do grupo PEUL/UFRJ dedicaram-se à breve classificação de MDs como olha, vê e viu? 
conversacionais; Marin Jordá (2003) também faz menção à gramaticalização ao analisar os MDs no catalão.

Com base na literatura pesquisada sobre os MDs derivados de verbo de percepção, notadamente nos trabalhos que investigaram diferentes amostras do PB, bem como nos trabalhos de diversas línguas românicas acima referidos, efetuamos nossa proposta de descrição de cada contexto de atuação discursiva de olha e vê nas amostras por nós analisadas. Nesse levantamento, foram identificados dez contextos de atuação discursiva, conforme se verá no quadro 1.

\section{(Inter)subjetividade e (inter)subjetivização, funções da linguagem e gramaticalização}

Nesta seção, expomos o suporte teórico que sustenta a análise apresentada neste artigo. Inicialmente, tratamos das noções de (inter)subjetividade e (inter) subjetivização, ilustradas com exemplos; na sequência, mostramos a relação desses mecanismos de mudança semântico-pragmática com as funções da linguagem; por fim, relacionamos os processos de (inter)subjetivização e as funções da linguagem com a gramaticalização.

No âmbito dos estudos de mudança semântica em geral, e também de gramaticalização, costuma vir à baila a atuação de dois mecanismos, o primeiro de natureza cognitiva e o segundo de natureza comunicativa/pragmática: a metáfora - mudança de domínio conceitual, atuando no plano paradigmático; e a metonímia - fortalecimento pragmático por meio da convencionalização de uma implicatura conversacional, atuando no plano associativo. No primeiro caso, a passagem de um domínio a outro se dá de modo discreto; no segundo, a força pragmática se manifesta num continuum refletido em etapas com significados sobrepostos, cuja expansão resulta no que Heine, Claudi e Hünnemeyer (1991) denominam reinterpretação induzida pelo contexto.

Além da metáfora e da metonímia, Traugott (2002, 2003b, 2010) prevê dois outros mecanismos cognitivos e comunicativos de mudança semântica em geral: a subjetivização - processo que se desenvolve a partir do uso de expressões cujo significado é o de indexar a atitude ou ponto de vista do falante em relação ao conteúdo do que é dito; e a intersubjetivização - processo que se desenvolve a partir do uso de expressões cujo significado é o de indexar a atenção do falante à face/imagem do ouvinte. A partir do uso de expressões de subjetividade e de intersubjetividade ${ }^{8}$ é que se desenvolvem polissemias, de início pragmáticas, depois com significados semanticamente codificados.

8 Na abordagem defendida por Traugott (2002, 2003b, 2010), a (inter)subjetividade é observada numa perspectiva sincrônica, enquanto a (inter)subjetivização é percebida diacronicamente. 
Traugott (2010) faz uma distinção entre usos que correspondem a (inter) subjetivização e usos que correspondem a aumento de (inter)subjetividade pragmática. Subjetivização e intersubjetivização são mecanismos que envolvem uma reanálise semântica: significados pragmáticos que emergem no contexto de negociação de sentidos pelos interlocutores são reanalisados como significados semânticos codificados. De acordo com Traugott (2002), as polissemias com significado semanticamente codificado podem, mais tarde, vir a ser reinterpretadas como homonímias, ou até mesmo deixar de ser usadas. Então, o movimento de mudança de significação se daria nessa direção: polissemia pragmática $>$ polissemia semântica $>$ homonímia. No processo de expansão polissêmica é que se encontram usos de expressões de (inter) subjetividade, os quais, como veremos adiante, podem se constituir em instâncias de gramaticalização.

Um exemplo frequentemente citado nos trabalhos de Traugott (2003b, 2010) é o que envolve o uso de let's no inglês (TRAUGOTT; DASHER, 2002):

\begin{tabular}{|c|c|c|c|}
\hline let us $X^{\prime}$ permit us to X' (IMP) & & let's 'I propose' (hortativo) > & 'mitigador' \\
\hline Let us go, will you & $>$ & Let's go, shall we & Let's take our pills now, Johnny \\
\hline intersubjetividade inerente & $>$ & polissemia orientada $\mathrm{p} / \mathrm{o} \mathrm{F}>$ & aumento de intersubjetividade \\
\hline
\end{tabular}

A construção imperativa let us $X$ (permita-nos $X)^{9}$ é originariamente intersubjetiva - isto é, inerente ao contexto de sujeitos sintáticos (na estrutura argumental) que envolvem o interlocutor -, pois o enunciado tem força ilocucionária: F e O são participantes no evento projetado, uma vez que a construção é endereçada de P1 a P2. Fora dessa construção, que pode ser expandida para Let us go, will you!, emerge uma polissemia orientada para o F: let us (> let's), conhecida como let's hortativo ou exortativo. Aqui, P1 e P2 juntos são sujeito sintático de let e de go, como em Let us go, shall we? Essa construção é mais subjetiva, pois o falante se inclui na exortação, além de ser uma forma mitigada de um imperativo; e é também mais intersubjetiva, pois o $\mathrm{O}$ é agora tomado como agente junto do F. Usos mais recentes de let's mostram um aumento de intersubjetividade, como nos casos que incluem locuções dirigidas a pacientes ou a crianças, em que o $\mathrm{F}$ presumivelmente não é um participante no evento tomar pílula em: Let's take our pills now, Johnny (Vamos tomar nossas pílulas agora, Johnny). Esse tipo de posicionamento do F mitiga fortemente a intenção, que é imperativa (Tome suas pílulas agora, Johnny!) e explicitamente marca atenção intersubjetiva para com o ouvinte.

9 Esse tipo de construção é atestado desde o inglês antigo até hoje. 
Como se depreende do exemplo acima, o que interessa não é apenas o caráter contextual da situação de interlocução - no caso, a intersubjetividade característica do ato de fala manipulativo -, mas principalmente a presença de marcadores e expressões linguísticas que indexam a subjetividade e a intersubjetividade, e a descoberta de como eles emergem. Outro dado ilustrativo é o uso rotinizado de sujeitos de P2 (indicadores inerentes de intersubjetividade), com propósitos subjetivos para negociar o significado pretendido pelo falante, em construções do tipo you see e y'know, como em "I've got something to tell you, my dear, said Caleb in his hesitating way... You see, I've been a bit of a fool again, and put my name to a bill- 1871 Eliott, Middlemarch [UVa]" (TRAUGOTT, 2010, p.48, grifo do autor)..$^{10}$

O aumento de intersubjetividade nos casos acima descritos está associado a uma mudança de significados de conteúdo (baseados na estrutura argumental no nível oracional) para significados procedurais pragmáticos (relacionados com estratégias comunicativas no nível discursivo). Particularmente, os usos de let's e you see mostram que mesmo enunciados imperativos, que são inerentemente intersubjetivos, podem ser (inter)subjetivizados. ${ }^{11}$ Esses exemplos são bastante pertinentes à análise dos MDs olha e vê, desenvolvida adiante.

Um ponto de partida de Traugott $(1982,1989)$ para conceituar a (inter) subjetividade e a (inter)subjetivização é a distinção entre os componentes do sistema linguístico propostos inicialmente por Halliday e Hasan (1976) ideacional, textual e interpessoal -, renomeados pela autora como proposicional, textual e expressivo. Diga-se, de passagem, que essa classificação tripartida revisitada pelos estudiosos da gramaticalização é fundamental para a discussão acerca da multifuncionalidade dos MDs. Sob uma perspectiva diacrônica, Traugott (1989) sugere que, em muitos casos, um item lexical que se origina no componente ideacional desenvolve mais tarde polissemias nos domínios textual e expressivo, nesta ordem: proposicional $>$ ((textual) $>$ (expressivo)). O componente textual inclui elementos que servem à conexão local (como relativizadores e complementizadores) e também elementos que servem mais a propósitos procedurais de expressar a atitude do falante (como topicalizadores e marcadores discursivos), alguns deles sobrepondo as duas funções (como and/e, then/então, in fact/de fato) - todos tidos como ingredientes essenciais da gramática. O componente expressivo é posteriormente desdobrado em subjetivo

10 "Tenho algo a lhe dizer, querida, disse Caleb em seu tom hesitante... Veja, eu fui um tanto tolo novamente, e assumi uma dívida" (TRAUGOTT, 2010, p.48, grifo do autor, tradução nossa). No caso específico desse exemplo, a autora coloca em foco também o uso da construção a bit of a fool (um tanto tolo), considerando a mudança: a bit of (um pedaço de) partitivo > modificador de grau, como um caso de subjetivização.

11 Veja-se também o caso do MD say em muitos de seus significados (assume, about, for example, tell me). Say deriva de um uso imperativo, naturalmente intersubjetivo portanto, mas é subjetivizado ao longo do tempo: o uso about é um tipo de topicalizador, e o uso tell me expressa impaciência do F (BRINTON, 2005 apud TRAUGOTT, 2010). 
(orientado para o falante) e intersubjetivo (orientado para o ouvinte) (TRAUGOTT; DASHER, 2002).

Em trabalho mais recente, Traugott (2010) correlaciona o cline de (inter) subjetividade, que segundo ela deve ser visto como camadas (HOPPER, 1991) - no sentido de que significados mais antigos coexistem com significados mais recentes de um mesmo item -, à proposta de Halliday e Hasan (1976), focalizando os componentes ideacional e interpessoal. Observe-se que, aqui, o componente textual é omitido, uma vez que o componente mais relevante para a discussão da autora é o interpessoal.

$\begin{array}{lll}\text { não-/menos subjetivo } & >\text { subjetivo }>\text { intersubjetivo } \\ \text { ideacional } & >\text { interpessoal }\end{array}$

Esse continuum, segundo a autora, sintetiza tendências de mudança: a intersubjetivização é um mecanismo posterior e surge como uma extensão da subjetivização.

Considerando particularmente o componente da função interpessoal orientado para o ouvinte, Heine, Claudi e Hünnemeyer (1991) sugerem um cline diferente daquele postulado por Traugott $(1982,1989)$, deslocando a função textual para o final da trajetória: ideacional > interpessoal > textual. A argumentação dos autores se pauta basicamente no seguinte: as situações mais nítidas de interação com o ouvinte envolvem atos de fala manipulativos com enunciados de perguntas e de comandos. Formas interrogativas (como who) e imperativas (como suppose) podem se desenvolver em elementos que atuam no plano textual, relacionando orações e estabelecendo elos coesivos no texto. A passagem da função interpessoal para a textual seria motivada por uma estratégia do falante chamando a atenção para determinada parte do texto. Com o tempo, essa relação passaria gradualmente a ser reinterpretada como uma relação entre diferentes partes do texto, evidenciando-se aí a função textual.

Não é nossa intenção discutir aqui a ordenação dos componentes das duas trajetórias mencionadas no parágrafo acima, nem as diferentes nuanças conceituais observadas nas perspectivas dos autores. ${ }^{12} \mathrm{O}$ que interessa para os propósitos deste trabalho é a associação estabelecida entre os processos de mudança e as funções da linguagem. Nesse sentido, é relevante para nós o fato de que Heine, Claudi e Hünnemeyer (1991) consideram a passagem da função interpessoal para a textual como instância de gramaticalização.

Gramaticalização é entendida, neste artigo, como "mudança pela qual itens lexicais e construções passam, em certos contextos linguísticos, a desempenhar

12 Para uma discussão dessas trajetórias, remetemos o leitor ao trabalho de Görski, Rost e Dal Mago (2004). 
funções gramaticais e, uma vez gramaticalizados, continuam a desenvolver novas funções gramaticais" (HOPPER; TRAUGOTT, 2003a, p.18). E conforme especificada por Traugott (1995, p.1, grifo nosso): "processo pelo qual um item lexical [ou uma construção], impulsionado por certo contexto pragmático e morfossintático, torna-se gramatical". A autora enfatiza que se trata do desenvolvimento de itens lexicais em contextos de construções específicas (TRAUGOTT, 2003a).

Qual a relação da (inter)subjetivização com a gramaticalização? Traugott (2010) afirma que a subjetivização está bastante atrelada à gramaticalização, bem mais do que a intersubjetivização, uma vez que esta se restringiria, de modo geral, a expressões de polidez, tendendo a ser mais associada a escolhas lexicais do que gramaticais. Essa estreita interação se deve ao fato de que ambos os processos - subjetivização e gramaticalização - envolvem o desenvolvimento de marcadores de atitude do falante em relação ao componente ideacional e à conectividade textual, entre outros. É na gramaticalização primária, em que acontece mudança de lexical/construcional para gramatical (diferente da gramaticalização secundária, que envolve o desenvolvimento de material já gramatical em mais gramatical), que a subjetivização se manifesta mais. Traugott (2002) pontua que antes da gramaticalização ocorre uma polissemia pragmática, ou seja, o uso de inferências sugeridas generalizadas (termo preferido pela autora em vez de implicaturas). Dito de outro modo, significados pragmáticos inferidos do contexto, correspondentes ao aumento de (inter)subjetividade pragmática, impulsionam a gramaticalização.

No domínio da subjetivização, encontram-se evidências de gramaticalização oriundas do desenvolvimento de verbos de atos de fala e especialmente de seus usos ilocucionários. Traugott (2010) chama a atenção para o fato de que elementos subjetivizados tendem a se posicionar na periferia de um constituinte ou oração. É o caso, por exemplo, da evolução do nome japonês wake (reason) para um MD situado no final do enunciado, traduzido para o inglês como no wonder ou you see (você vê). Estamos cientes de que não é consensual a atribuição de estatuto de gramaticalização a casos desse tipo, especialmente quando há aumento de escopo envolvido. Assumimos, no entanto, a posição de Traugott (2010) que considera esses casos como gramaticalização.

Ainda como embasamento teórico para a análise dos MDs, a par de considerar trajetórias de mudança implicadas nas funções da linguagem, acionamos também o conjunto inter-relacionado de parâmetros propostos por Heine e Kuteva (2007), que evidenciam perdas, e também ganhos, em diferentes níveis linguísticos nos processos de mudança por gramaticalização: 
a. extensão, i.e., o surgimento de novos significados gramaticais quando expressões linguísticas são estendidas a novos contextos (reinterpretação induzida pelo contexto): ${ }^{13}$

b. dessemantização (ou "apagamento semântico"), i.e., perda (ou generalização) em conteúdo de significado;

c. descategorização, i.e., perda em propriedades morfossintáticas características de formas lexicais ou de outras formas menos gramaticalizadas;

d. erosão (ou "redução fonética"), i.e., perda em substância fonética (HEINE; KUTEVA, 2007, p.34, tradução nossa).

Cada um desses parâmetros recobre diferentes aspectos da língua em uso. A extensão é de natureza pragmática, a dessemantização capta o nível semântico, a decategorização exibe a natureza morfossintática e a erosão reflete o nível fonético da categoria linguística. A ordenação desses parâmetros reproduz a sequência diacrônica em que eles são aplicados nos itens em processo de gramaticalização. Enquanto os três últimos envolvem perda de propriedades, o primeiro aponta para ganhos com usos em novos contextos.

\section{Procedimentos metodológicos}

Nesta seção, descrevemos brevemente os procedimentos analíticos adotados e as amostras analisadas. Assumimos uma perspectiva pancrônica, entendendo a mudança linguística como um processo contínuo. Nesse sentido, considerando o princípio do uniformitarismo, partimos do mapeamento da multifuncionalidade dos itens em dados atuais e, uma vez reconhecido o terreno sincrônico, recorremos a amostras de momentos anteriores da língua para buscar indícios do funcionamento dos MDs olha e vê ao longo do tempo, considerando sempre a questão do contexto. Procuramos, ao incorporar dados de diferentes épocas, verificar indícios do desenvolvimento conjunto e individual das formas sob análise, considerando a mudança semântico-pragmática e categorial por que passaram esses itens. Na seção de análise, os resultados sincrônicos e diacrônicos são discutidos conjuntamente.

13 Segundo Heine e Kuteva (2007), a extensão tem três componentes: um sociolinguístico, outro pragmáticotextual e um terceiro semântico. O componente sociolinguístico tem a ver com a inovação e a propagação; o componente pragmático-textual envolve a extensão de um contexto usual para novo(s) contexto(s) e a disseminação gradual para contextos mais gerais; o componente semântico concerne à expansão de um significado existente para outro que é evocado ou suportado pelo novo contexto. Os componentes pragmático e semântico são dois lados de um mesmo processo que caracteriza a emergência de novas estruturas gramaticais. 
Consideramos que um importante fator relacionado à gramaticalização é a frequência de uso - vista não como um resultado, mas como um indício para a sua identificação -, notadamente no que diz respeito à extensão de uso da forma a novos contextos com novas associações pragmáticas (BYBEE, 2003), daí a importância atribuída à quantificação dos dados. Para caracterizar um processo de gramaticalização, é necessário, portanto, não só mapear as funções, mas também quantificar as ocorrências.

Duas amostras foram analisadas, identificadas como corpus sincrônico (amostra oral) e corpus diacrônico (amostra escrita). A amostra de fala é constituída por entrevistas sociolinguísticas de 96 informantes catarinenses integrantes do Projeto VARSUL ${ }^{14}$, distribuídos em quatro localidades: Florianópolis, Blumenau, Chapecó e Lages. São 24 informantes por cidade, socialmente estratificados quanto às variáveis: idade (de 25 a 49 e acima de 50 anos), escolaridade (antigos primário, ginasial e colegial) e sexo.

A amostra escrita é formada por dezessete peças teatrais de autores catarinenses, integrantes do "Banco de dados diacrônicos de Santa Catarina", 15 vinculado ao Projeto VARSUL. A opção por peças se deve à tentativa de minimizar o "paradoxo histórico", no sentido de "fazer o melhor uso de maus dados" (LABOV, 1994, p.11), pois se supõe que as peças devem apresentar, na medida do possível, linguagem próxima à fala da época, embora reconheçamos que, devido à natureza do objeto, não se trata de dados abundantes e que alguns aspectos interacionais deixam de ser evidenciados em decorrência de restrições impostas na transferência da modalidade oral para a escrita. ${ }^{16}$

Considerando-se como critério o ano de nascimento do autor, dispomos de sete peças do século XIX e dez do século XX: Raimundo, 1868, de Álvaro Augusto de Carvalho (1829-1965); Brinquedos de cupido, 1898, de Antero dos Reis Dutra (1835-1911); A casa para alugar, 1867, de José C. de Lacerda de Coutinho (18411902); Os ciúmes do capitão, 1880, de Arthur Cavalcanti do Livramento (18531897); O idiota, 1890, de Horácio Nunes Pires (1855-1919); A engeitada [sic], 1930, de Joaquim São Thiago (1857-1916); A filha do operário, 1942, de Ildefonso Juvenal (1894-1965); A taverna do gato branco, 1954, de Arnaldo Silveira Brandão (1922-1976); O dia do javali, 1983, de Mauro Júlio Amorim (1939-); O contestado, 1972, de Romário José Borelli (1943-); Stradivarius, 1993, de Augusto Nilton de Sousa (1944-); Em tua homenagem ou não, 1984, de José Darci Silva Júnior; Os

14 Detalhes sobre a constituição do banco de dados VARSUL podem ser conferidos em Projeto Varsul (2010).

15 O Banco de dados diacrônicos é constituído de textos a partir do século XIX, uma vez que a imprensa em Santa Catarina foi fundada somente em 1831. Embora o Banco disponha de mais peças de um mesmo autor, selecionamos apenas um texto de cada um dos 17 autores catarinenses que integram a amostra.

16 Como algumas peças de teatro apresentam número de páginas mais extenso, para que houvesse certo equilíbrio entre os textos, procedemos à captação do fenômeno numa extensão entre 20 a 40 páginas. 
lobos, 1992, de Ademir Rosa, (1950-1997); Metacor, 1983, de Iberê do Nascimento (1959-); As quatro estações, 1998, de Antonio Cunha (1961-); Prenome: Fausto, 1993, de Fábio Brüggemann (1962-) e Uma longa história de amor, 1999, de Néri Gonçalves de Paula (1963-).

Cabe ainda uma observação a respeito da unidade de análise. Embora a conversação seja desenvolvida com base na troca de turno, podendo englobar porções de texto maiores ou menores, delimitamos como unidades de análise trechos que veiculam um significado semântico-pragmático proeminente, contextos em que os MDs auxiliam na expressão de diferentes funções comunicativas (advertência, surpresa, opinião, entre outras), seja na introdução, no desenvolvimento ou no fechamento dessas unidades temáticas (ROST SNICHELOTTO, 2009). Essas unidades ficarão mais bem evidenciadas adiante. Os critérios definidores dos contextos de atuação discursiva dos itens sob análise serão ancorados no desenvolvimento da seção seguinte.

\section{Análise pancrônica do comportamento (multi)funcional de olha e vê}

Nesta seção, nosso interesse incide na descrição do comportamento (multi) funcional exibido por olha e vê nas amostras escrita e oral. A seguir, abrimos uma breve subseção dedicada à mudança semântico-pragmática e categorial e outra destinada aos aspectos formais dos itens; na sequência, nos debruçamos nos contextos de atuação discursiva dos MDs.

\section{Mudança semântico-pragmática e categorial de olha e vê}

A partir do levantamento das ocorrências relativas ao contexto de ato de fala manipulativo típico de P2, olha e vê foram distribuídos em duas categorias: (i) formas verbais de percepção, com valor dêitico espacial, visto que há um comando explícito do $\mathrm{F}$ para o $\mathrm{O}$ direcionando o olhar/a visão deste último - olha e vê atuam como item lexical pleno em atos de fala claramente diretivos -; e (ii) MDs que vão expandindo seu significado de base e, conforme Risso (1999), a referência à percepção visual aparece remanejada para a expressão de outra espécie de envolvimento sensório-cognitivo, isto é, altera-se o ponto de referência do campo visual (situações objetivas) para o da ação mental (situações (inter)subjetivas) olha e vê se deslocam de sua posição verbal, perdendo o elo sintático explícito com o enunciado.

A sequência de trechos a seguir mostra um gradiente funcional com expansões de uso de olha e de vê. Tais expansões provavelmente não ocorrem numa linearidade cronológica fixa, pois os usos podem se expandir 
em polissemias pragmáticas em mais de uma direção num mesmo momento. Nossa intenção aqui é apenas evidenciar instâncias de mudança semânticopragmática e categorial. ${ }^{17}$

(1) DALTON - Olhe, aqui estão todos os objetos e roupas que ela usava. (Larga tudo no centro da cena). Vestidos, calcinhas, soutiens, sapatos... Hummm! Ela ficava tão bem com esses soutiens, a caixa de maquiagem, um estojo de joias e bijouterias... (Pausa) Ela tinha o péssimo costume de dormir abraçada com este ursinho, eu detesto esse urso. Eu trouxe até a agenda que ela usava, veja, apesar de estar em branco, tem o nome dela gravado aqui na capa, algumas revistas, as prediletas [...] (SILVA JÚNIOR, 1984, p.24).

(2) ELVIRA - (Descendo pela esquerda.) Perfeitamente. Mas previna-o de que não saio hoje de casa. Quero rir-me à custa desse tolo e fazê-lo andar aqui numa roda viva. MACÁRIO - (Fechando a carta.) Vê lá... o rapaz é rico e não é para desprezar... ELVIRA - Deixe-o por minha conta. Esperarei ocasião oportuna para aparecer-lhe. O papai não se admire do que fizer!

MACÁRIO - (Endereçando a carta.) Toma cuidado, menina... Às vezes a gente pensa uma coisa e ela é outra... Não vá o chumbo virar por cima da cortiça... (PIRES, 1999, p.222).

(3) Menino 01: Ainda bem que só falta mais um . (Escreve) Acabei!

Menino 02: Eu também !...

Menino 01: Sabe que esse negócio de escrever com duas canetas rende mesmo.

Olha, se não fosse isso, nós ficávamos aqui até de noite!

Menino 02: E agora... A gente faz o quê ? Esperamos aqui - ou levamos lá?... (PAULA, 1999, p.156).

(4) IDIOTA - Não pense tanto assim, eu me atrapalho. Como pode pensar tanto, ter tantas dúvidas?

FAUSTO - Talvez porque eu não me chame Idiota. Infelizmente me chamo, não sei por quanto tempo neste drama, Fausto. Sabe o que significa Fausto, Idiota? Quer dizer, veja só, Idiota, feliz. No fundo, ser feliz e ser idiota dá quase no mesmo (BRÜGGEMANN, 1999, p.61).

Em (1), olhe e veja apresentam um estatuto verbal definido, referindo-se a uma situação contextual concreta, com explícita remissão do falante ao ouvinte para que atenda ao comando expresso pelo verbo (dêitico locativo). No exemplo (2), nota-se que o item se reveste de certo grau de abstratização e expande seu sentido de base para expressar, por exemplo, uma espécie de advertência cuidado

17 Por uma questão de espaço, optamos por mesclar dados ora de um ora de outro MD e apresentar basicamente exemplos da amostra escrita. Ocorrências que evidenciam essa trajetória, coexistindo sincronicamente, são encontradas também na oralidade (ROST SNICHELOTTO, 2009). 
com. Já a ocorrência (3) mostra um contexto de interpretação ambígua: olha pode ser interpretado como verbo pleno olhar cujo complemento dêitico poderia ser "as duas canetas", ou como MD, revestindo-se de sentido mais abstrato e revelando certa surpresa com relação ao relatado/exposto, o que caracterizamos, conforme se verá adiante, como contexto interjetivo. Em (4), veja só perde parte do sentido de percepção visual, sofrendo desbotamento semântico e adquirindo um sentido de inferência mental uma vez que a atenção do ouvinte é metaforicamente deslocada do espaço físico para o espaço discursivo; nesse contexto, o MD apresenta valor de presta atenção.

Nas ocorrências seguintes, olha aparece contíguo a mas, o que parece reforçar o valor relacional do $\mathrm{MD}$.

(5) FELIPE - Afinal, que novidades trouxeram vocês? Como ocorreram as manifestações desta manhã? O pessoal levou a efeito o comício na Praça Municipal?

ROQUE - Como não!? Foi um sucesso! Mas olha: acabou em pau... A polícia interviu e choveu chanfalho e pata de cavalos. (JUVENAL, 1942, p.99).

Como vimos nos exemplos (1) a (5), elementos designativos de espaço [+concreto] passam a ser usados como organizadores do universo discursivo [-concreto] (HEINE; CLAUDI; HÜNNEMEYER, 1991). Entre esses níveis, delimitados de forma mais ou menos discreta como domínios metafóricos distintos, há um continuum de pequenas mudanças que se dão metonimicamente, por contiguidade contextual, em que um uso dá origem a outro. Esse movimento mostra um duplo deslocamento: desbotamento do conteúdo semântico com ganho pragmático-discursivo e mudança gradativa do estatuto categorial - de verbo a MD -, conforme atestam estudos de diversas línguas românicas cujos verbos de percepção visual olhar e ver também derivam MDs. Um detalhamento dos diferentes contextos de atuação discursiva desses itens será feito adiante.

Com uma trajetória parecida e compartilhando contextos de uso, esses dois marcadores discursivos podem ser inseridos num mesmo domínio funcional, rotulado como chamada de atenção do ouvinte e identificado a partir de uma propriedade de natureza interpessoal - um ato manipulativo de comando. No interior desse domínio funcional, olha e vê atuam como formas concorrentes, podendo ser tratados como variantes de uma variável linguística em grande parte de seus contextos de atuação discursiva. Não vamos tratar da variação entre os itens neste artigo. Em relação a uma análise variacionista, remetemos o leitor à tese de Rost Snichelotto (2009). 


\section{Aspectos formais dos MDs olha e vê}

Nas amostras analisadas foram feitos dois tipos de levantamento de dados: nas peças teatrais, foram coletadas todas as ocorrências de olhar e ver, independentemente do tempo verbal e da pessoa do discurso; nas entrevistas do VARSUL, a coleta restringiu-se aos contextos de P2, que caracterizam os MDs em estudo. As Tabelas 1 e 2 apresentam, respectivamente, o total de ocorrências de MDs derivados de olhar e ver nas amostras investigadas. Na amostra escrita, constam também as ocorrências das respectivas formas verbais.

Tabela 1 - Distribuição das ocorrências de formas verbais e MDs derivados de olhar por amostra

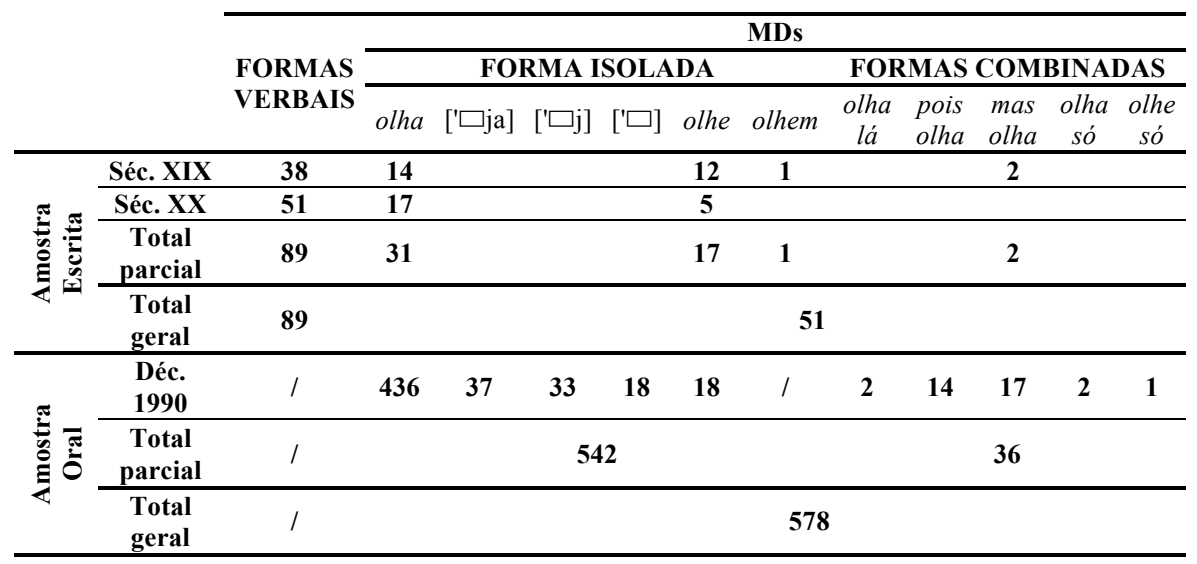

Fonte: Adaptada de Rost Snichelotto (2009, p.233, 293).

Atentemos inicialmente para os resultados da amostra escrita. A distribuição de olhar apresenta particularidades interessantes. No século XIX, foram encontrados 38 verbos e 29 MDs (43\% dos usos de olhar são de MD); no século XX a proporção de marcadores fica um pouco menor: 51 verbos e 22 MDs (30\% de MDs). Como se trata de registro escrito, essa frequência relativamente alta de MDs, já no século XIX, é um indício forte de que os usos de olha como marcador discursivo devem ter emergido bem antes disso.

Observemos agora as formas dos MDs. As ocorrências do século XIX se concentram em duas formas de P2 (olha $=14$ dados e olhe $=12$ dados), com apenas uma ocorrência de olhem. No século XX, também há concentração em P2, porém a proporção da forma derivada do modo indicativo (IND) é aproximadamente três vezes maior que a do subjuntivo (SUBJ) (olha = 17 dados e olhe $=5$ dados). Esse resultado pode ser indício de que: (i) esse MD já se encontra formalmente fixado em P2 no século XIX; (ii) deve haver resquícios da forma verbal associada 
aos pronomes tu e você. ${ }^{18}$ Pode-se inferir, desses resultados, que a forma olha vai se fixando independentemente do pronome de P2 usado.

Na amostra oral, como já foi dito, computamos somente as ocorrências de MD como P2. Destacam-se: alguns usos recorrentes de formas combinadas com elementos conectores e adverbiais, provavelmente em processo de cristalização; a significativa preferência pela forma derivada do IND: 471 ocorrências (81\%) de olha (considerando as realizações isoladas e combinadas) versus 19 ocorrências (3\%) de olhe. Se projetarmos que os 88 casos de semivocalização e de redução fonética de olha decorrem da forma do IND, ${ }^{19}$ o percentual de realização do MD olha por meio de formas derivadas do modo IND chega a 97\% dos dados.

Quanto à redução fonética de olha, ao se observar a escala em direção à maior redução ([' ja] > [' j] > [' ]), nota-se a correspondente diminuição do número de ocorrências $(37>33$ >18). Evidencia-se, aqui, a atuação do parâmetro da erosão (HEINE; KUTEVA, 2007), que pode ser explicado em termos de frequência de uso: palavras que são frequentemente repetidas no discurso tendem mais a ser encurtadas do que elementos de baixa frequência (BYBEE, 2003).

A tabela a seguir, adaptada de Rost Snichelotto (2009), apresenta as ocorrências de formas verbais e MDs derivados de ver nas amostras investigadas.

Tabela 2 - Distribuição das ocorrências de formas verbais e MDs derivados de ver por amostra

\begin{tabular}{|c|c|c|c|c|c|c|c|c|c|c|c|c|c|}
\hline & & \multirow{3}{*}{$\begin{array}{l}\text { FORMAS } \\
\text { VERBAIS }\end{array}$} & \multicolumn{11}{|c|}{ MDs } \\
\hline & & & \multicolumn{6}{|c|}{ FORMA ISOLADA } & \multicolumn{5}{|c|}{ FORMAS COMBINADAS } \\
\hline & & & $v \hat{e}$ & vês & veja & $\begin{array}{c}\text { vamos } \\
\text { ver }\end{array}$ & vejamos & vejam & vê bem & vê só & vê lá & $\begin{array}{l}\text { veja } \\
\text { bem }\end{array}$ & $\begin{array}{c}\text { veja } \\
\text { só }\end{array}$ \\
\hline \multirow{4}{*}{ 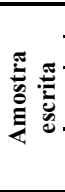 } & Séc. XIX & 118 & & & & 1 & 3 & & & & 1 & & \\
\hline & Séc. XX & 184 & & & 3 & 2 & & 1 & & & & 1 & 3 \\
\hline & $\begin{array}{c}\text { Total } \\
\text { parcial }\end{array}$ & 302 & & & 3 & 3 & 3 & 1 & & & 1 & 1 & 3 \\
\hline & $\begin{array}{l}\text { Total } \\
\text { geral }\end{array}$ & 302 & & & & & & & 5 & & & & \\
\hline \multirow{3}{*}{ 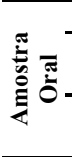 } & Déc. 1990 & 1 & 83 & 2 & 13 & 1 & 1 & 1 & 1 & 2 & $\mathbf{0}$ & 23 & 7 \\
\hline & $\begin{array}{c}\text { Total } \\
\text { parcial }\end{array}$ & I & & & & 98 & & & & & 33 & & \\
\hline & $\begin{array}{l}\text { Total } \\
\text { geral }\end{array}$ & l & & & & & & & 31 & & & & \\
\hline
\end{tabular}

Fonte: Adaptada de Rost Snichelotto (2009, p.236).

18 Loregian-Penkal (2004) evidencia, para a mesma amostra oral por nós analisada, a seguinte distribuição de uso dos pronomes tu e você em Santa Catarina: $23 \%$ dos informantes usam apenas a forma tu; $14 \%$ usam apenas você; e 63\% fazem uso variável das duas formas pronominais.

19 Estamos fazendo uma projeção hipotética mas que consideramos plausível, já que não foi encontrada nenhuma forma de ['oji] ou ['oje], que pudesse ser identificada como um caso de semivocalização de olhe. No entanto não fica descartada a possibilidade de olhe $>$ ['oj] $>$ ['o] 
Iniciemos a análise pela amostra escrita. O item ver apresenta um comportamento diferenciado em relação a olhar: é um item bem mais produtivo no seu emprego verbal (séc. XIX - 118 ocorrências do verbo ver para apenas 38 do verbo olhar; séc. XX - 184 ocorrências do verbo ver para 51 de olhar). Por outro lado, o uso de ver como MD é bem mais reduzido (séc. XIX - 4\% das ocorrências de ver na amostra (118 verbos e 5 MDs) são de MD; séc. XX - 5\% dos usos (184 verbos e $10 \mathrm{MDs}$ ) são de MD. Já o percentual de olhar como MD é de $43 \%$ e 30\%, respectivamente por século).

Quanto à forma dos MDs, no século XIX, foram encontradas, nas peças analisadas, 4 ocorrências em P4 (vejamos, vamos ver) e uma em P2 (vê lá). Já no século XX, a incidência maior é de P2 (veja), totalizando 7 dados entre formas isoladas e combinadas.

Ainda olhando comparativamente para os MDs: na amostra escrita, são 66 ocorrências totais (51 para olha e 15 para vê) entre as quais predomina largamente o MD olha em P2 (50/66 = 76\%), em contraste com vê em P2 (9/66 = 13\%). Vale observar também que, enquanto em apenas duas das dezessete peças examinadas não se verificou nenhuma ocorrência do $\mathrm{MD}$ olha em $\mathrm{P} 2$, em treze peças não houve registro de vê.

Quanto à amostra escrita, fica nítido que: (i) enquanto o MD olha já se fixa em P2 desde o século XIX, o MD vê começa a se fixar em P2 no século XX; (ii) enquanto para olha a forma derivada do SUBJ (olhe) vai recuando no século XX em favor da forma derivada do IND (olha), para vê, é a forma derivada do SUBJ (veja) que ganha espaço no século XX. Temos, pois, que as formas dos MDs predominantes nas peças teatrais catarinenses do século XX são: olha (derivada do IND) e veja (derivada do SUBJ).

$\mathrm{Na}$ amostra oral, a frequência de formas combinadas de vê em relação a formas isoladas $(33 / 131=25 \%)$ é relativamente maior que a de olha $(36 / 578=6 \%)$. A exemplo de olha, as formas de vê derivadas do IND (88 ocorrências) também suplantam as do SUBJ (43 ocorrências), porém em proporção relativamente menor: $97 \%$ de olha e $67 \%$ de vê. Os resultados apontam que os catarinenses, na fala coletada na década de 1990, elegem as formas derivadas de IND - olha e vê para expressar valores de MD.

Notamos, portanto, uma trajetória diferenciada em Santa Catarina no que se refere à forma dos MDs: enquanto nas peças a forma preferencial vai se intensificando rumo a olha (IND) e é nitidamente veja (SUBJ), nas entrevistas o uso predominante é de olha (IND) e vê (IND). 


\section{Aspectos funcionais dos MDs olha e vê}

Nesta seção, focamos a atenção nos contextos de atuação discursiva de olha e vê. Algumas considerações devem ser feitas inicialmente. A primeira diz respeito à identificação e delimitação desses contextos, tarefa levada a cabo com apoio, basicamente, na literatura sobre os MDs derivados de verbo de percepção nas línguas românicas. A delimitação dos contextos nem sempre é clara e frequentemente nos deparamos com sobreposições e interpretações ambíguas. Isso, no entanto, não é um empecilho para a análise, já que a perspectiva funcionalista prevê que a força pragmática se manifesta num continuum refletido em etapas com significados sobrepostos, levando a (re)interpretações sugeridas pelo contexto. Em termos metodológicos, porém, a gradiência acaba sendo discretizada, mas de modo escalar e não binário (MARTELOTTA, 1998; URBANO, 1999; GÖRSKI, 2008).

A segunda consideração concerne ao critério para a descrição dos contextos analisados. De acordo com a perspectiva teórica assumida neste trabalho, a suposição é que, a partir de um contexto inerentemente interacional de ato de fala imperativo, os itens vão incorporando traços de subjetividade advindos do envolvimento maior do F que expressa suas atitudes avaliativas seja em relação ao comportamento do interlocutor, ao seu próprio comportamento, seja em relação a situações relatadas ou a determinadas porções textuais. Nesse sentido, os MDs vão deslocando o foco do O para o próprio F. Nesse processo de subjetivização, os itens acabam adquirindo também certos traços de natureza textual, como a ocorrência em posições relacionais, assumindo um caráter coesivo bidirecional. Reiteramos que essa expansão polissêmica não se dá necessariamente numa linearidade cronológica fixa, podendo coocorrer expansões de contextos de uso em mais de uma direção. Portanto o continuum sugerido na ordenação descrita nesta seção não deve ser visto como linearmente rígido.

Feitas essas considerações, passemos à análise. Nas amostras examinadas, foram identificados dez contextos de atuação discursiva dos MDs olha e vê, dispostos no quadro 1, associados a autores que identificaram tais contextos em seus estudos (não necessariamente sobre esses MDs), com uma breve caracterização de cada um, adaptada por nós. 


\begin{tabular}{|c|c|}
\hline \multicolumn{2}{|c|}{ Contextos de atuação discursiva dos MDs olha e vê } \\
\hline $\begin{array}{l}\text { De advertência (PONS BORDERÍA, } \\
\text { 1998; ROST, 2002; WALTEREIT, } \\
\text { 2002; DOMÍNGUEZ PORTELA, } \\
\text { 2008). }\end{array}$ & $\begin{array}{l}\text { Esse tipo de contexto caracteriza-se como uma } \\
\text { espécie de alerta, conselho ou aviso direcionado ao } \\
\text { interlocutor. }\end{array}$ \\
\hline Adversativo (WALTEREIT, 2002). & $\begin{array}{l}\text { Uma dada declaração opõe os parceiros conversa- } \\
\text { cionais. O ouvinte infere algo a partir da declaração } \\
\text { de F e produz, na sequência, uma afirmação. Ao } \\
\text { retomar o turno, F expõe uma resposta contrária à } \\
\text { expectativa de } \mathrm{O} \text {. }\end{array}$ \\
\hline $\begin{array}{l}\text { De atenuação (CASTILHO, 1989; } \\
\text { SILVA; MACEDO, 1996; ROST, } \\
\text { 2002; DOMÍNGUEZ PORTELA, } \\
\text { 2008). }\end{array}$ & $\begin{array}{l}\text { Com o uso do MD, F ameniza e controla, por anteci- } \\
\text { pação, possíveis reações negativas do O a respeito } \\
\text { do que será expresso; ou seja, F se descompromete } \\
\text { com uma afirmação que poderia vir a ser inferida } \\
\text { negativamente por O. }\end{array}$ \\
\hline $\begin{array}{l}\text { Interjetivo (ROST, 2002; } \\
\text { WALTEREIT, 2002; DOMÍNGUEZ } \\
\text { PORTELA, 2008). }\end{array}$ & $\begin{array}{l}\text { Nesse contexto, o MD introduz um trecho que revela } \\
\text { surpresa ou decepção com relação ao relatado/ex- } \\
\text { posto. A entonação de F somada ao que é dito pode } \\
\text { provocar uma dada inferência no O. }\end{array}$ \\
\hline $\begin{array}{l}\text { De prefaciação (SCHIFFRIN, 1987; } \\
\text { RISSO, 1999, 2006; ROST, 2002, } \\
\text { DOSTIE, 2004). }\end{array}$ & $\begin{array}{l}\text { O MD introduz um trecho que indica certo retar- } \\
\text { damento do tópico da pergunta aberta pelo entre- } \\
\text { vistador. A resposta solicitada pelo entrevistador é } \\
\text { inferida ou apresentada mais tardiamente. }\end{array}$ \\
\hline $\begin{array}{l}\text { De parentetização (JUBRAN, } \\
\text { 2006). }\end{array}$ & $\begin{array}{l}\text { O MD insere-se num enunciado parentético em } \\
\text { que o F encaixa um comentário que não integra } \\
\text { diretamente a articulação tópica sugerida pelo en- } \\
\text { trevistador. O tópico, momentaneamente desviado, } \\
\text { é retomado assim que se fecharem os parênteses. }\end{array}$ \\
\hline $\begin{array}{l}\text { Exemplificativo (ROST, 2002; } \\
\text { DOSTIE, 2004; DOMINGUEZ; } \\
\text { ÁLVAREZ, 2005). }\end{array}$ & $\begin{array}{l}\text { Nesse tipo de contexto, o MD introduz uma sequên- } \\
\text { cia que visa reforçar com exemplos o que está sendo } \\
\text { dito por um ou outro dos interlocutores. }\end{array}$ \\
\hline De opinião. & $\begin{array}{l}\text { Trata-se de contexto em que um personagem/falan- } \\
\text { te faz uma avaliação e emite sua opinião sobre um } \\
\text { assunto/fato/pessoa. }\end{array}$ \\
\hline $\begin{array}{l}\text { Causal (ROST, 2002; MARÍN } \\
\text { JORDÁ, 2003; DOSTIE, 2004; } \\
\text { DOMINGUEZ; ÁLVAREZ, 2005; } \\
\text { DOMÍNGUEZ PORTELA, 2008). } \\
\end{array}$ & $\begin{array}{l}\text { Trata-se da sinalização de uma espécie de conexão } \\
\text { entre dois segmentos um dos quais encerra a cau- } \\
\text { sa }^{20} \text { que acarreta a consequência/efeito, explicação } \\
\text { ou conclusão contida no outro. }\end{array}$ \\
\hline $\begin{array}{l}\text { Concessivo (TRAVAGLIA, 2002; } \\
\text { ROST, 2002). }\end{array}$ & $\begin{array}{l}\text { Nesse contexto, a expressão e olhe lá (cristalizada } \\
\text { pelo uso) encerra um trecho que indica uma espécie } \\
\text { de limite de concessão. }\end{array}$ \\
\hline
\end{tabular}

Quadro 1 - A multifuncionalidade de olha e vê

Fonte: Adaptado de Rost Snichelotto (2009, p.229).

20 Empregamos o termo causa em sentido amplo, recobrindo outros significados como razão, explicação, justificativa (PAIVA, 1992). 
Para facilitar a análise conjunta das amostras examinadas, organizamos, na tabela 3, os resultados para cada um dos MDs. Os dados das peças estão apresentados apenas em número de ocorrências. Os dados das entrevistas, como são em quantidade maior, estão associados aos respectivos percentuais, calculados comparativamente entre os usos de olha e vê para cada contexto. Neste ponto, cabe uma ressalva: os resultados precisam ser considerados com certa cautela, pois são amostras de modalidades distintas que estão sendo comparadas, além de haver diferença quantitativa acentuada entre os dois universos. Acreditamos, no entanto, que o fato de a amostra escrita se restringir ao gênero peça teatral e se limitar ao mesmo espaço geográfico da amostra oral - ambas de natureza dialógica - atenua em certa medida as discrepâncias. Além disso, a análise não está a reboque dos resultados numéricos absolutos; a frequência permite a identificação da recorrência relativa de uso dos MDs nos diferentes contextos e auxilia na avaliação de estágios de mudança.

Tabela 3 - Distribuição pancrônica de olha e vê de acordo com os contextos de atuação discursiva em amostras escrita e oral

\begin{tabular}{|c|c|c|c|c|c|c|c|c|c|c|}
\hline \multirow[b]{3}{*}{ MDs } & \multicolumn{5}{|c|}{ Amostra escrita } & \multirow{2}{*}{\multicolumn{5}{|c|}{ Amostra oral }} \\
\hline & \multicolumn{2}{|c|}{ Século XIX } & \multicolumn{2}{|c|}{ Século XX } & \multirow{3}{*}{ TOTAL } & & & & & \\
\hline & olha & vê & olha & vê & & \multicolumn{2}{|c|}{ Olha } & \multicolumn{2}{|l|}{ vê } & \multirow{2}{*}{ TOTAL } \\
\hline Contextos & Ocor. & Ocor. & Ocor. & Ocor. & & Freq. & $\%$ & Freq. & $\%$ & \\
\hline De advertência & 17 & 1 & 16 & - & 34 & 105 & 98 & 2 & 2 & 107 \\
\hline Adversativo & 1 & - & - & - & 1 & 51 & 100 & - & - & 51 \\
\hline De atenuação & 2 & - & 3 & - & 5 & 64 & 100 & - & - & 64 \\
\hline Interjetivo & $6^{21}$ & - & 3 & 4 & 13 & 44 & 80 & 11 & 20 & 55 \\
\hline De prefaciação & - & - & - & - & - & 34 & 94 & 2 & 6 & 36 \\
\hline De parentetização & - & - & - & - & - & 8 & 35 & 15 & 65 & 23 \\
\hline Exemplificativo & 1 & - & - & - & 1 & 79 & 80 & 20 & 20 & 99 \\
\hline De opinião & - & - & - & 1 & 1 & 108 & 98 & 2 & 2 & 110 \\
\hline Causal & 1 & - & - & 2 & 3 & 83 & 51 & 79 & 49 & 162 \\
\hline Concessivo & - & - & - & - & - & 2 & 100 & - & - & 2 \\
\hline Total & 28 & 1 & 22 & 7 & 58 & 578 & 82 & 131 & 18 & 709 \\
\hline
\end{tabular}

Fonte: Adaptada de Rost Snichelotto (2009, p.304).

Observando os resultados da amostra escrita na tabela 3, adaptada de Rost Snichelotto (2009), notamos que cerca de 60\% dos MDs analisados (34/58) se encontram em contexto de advertência, situação predominante nos dois séculos. Os demais dados se pulverizam com poucas manifestações em diferentes contextos. Por outro lado, considerando o total da amostra oral, apenas 15\% dos MDs (107/709) são característicos do contexto de advertência. Podemos inferir

21 Nos dados diacrônicos, o contexto interjetivo reúne, no século XIX, também 1 dado de advertência/interjetivo e 1 dado de atenuação/interjetivo e, no século XX, 1 dado de advertência/interjetivo. 
desses resultados que aquelas ocorrências esporádicas de MDs nos demais contextos nas peças se intensificaram de modo significativo nos dados de fala atuais, além de os MDs se expandirem para novos contextos, especialmente o de prefaciação.

É no contexto de advertência que localizamos a primeira ocorrência do MD olha (em (6)) e a única ocorrência de vê (em (2)).

(6) JULIETA - E se ele nunca mudar de opinião?

PAULO - Há de mudar... há de mudar de opinião...

JULIETA - Olha, Paulo; queres saber o que eu faria em teu lugar?

PAULO - Vejamos...

JULIETA - Apresentar-lhe-ia simplesmente a mulher, que julguei digna de meu amor e do meu nome... (COUTINHO, 2001, p.55).

Provavelmente as ocorrências de olha e vê em contexto de advertência assinalem o início da mudança semântico-pragmática dos itens, visto que o ato de fala manipulativo começa a se enfraquecer, embora indexando claramente o O. Nas ocorrências (6) e (2), ao usarem os MDs olha e vê lá no início de sua fala, os personagens pretendem explicitamente direcionar a advertência para o interlocutor em função de suas ações realizadas ou pretendidas. Especialmente em (2), a ideia de advertência é realçada na última fala do personagem Macário: "Toma cuidado, menina...". Podemos observar nesses casos não só a intersubjetividade inerente do contexto de P2, mas também certa manifestação avaliativa do personagem/falante (subjetividade).

Em contexto adversativo, encontramos apenas uma ocorrência de olha na amostra escrita (ilustrada em (7)) e 51 ocorrências desse mesmo MD nas entrevistas, indicando o incremento dos contextos de uso dos MDs nos dados de fala.

(7) JOÃO ANDRÉ - E tu gostas dela?

RAIMUNDO - Eu?... amo-a, amo-a como louco! Tu nunca amaste, André, e por isso não podes avaliar o que se passa em mim.

JOÃO ANDRÉ - Alto lá! menas [sic] essa! Eu cá já tive amores; olha; andei maluco pela Zeferina, que vendia fruita [sic] no Rocio, em Lisboa; era uma mulher do tamanho do mastro da gata... (CARVALHO, 1994, p.38).

Em (7), há um contraste no diálogo entre os personagens. Nesse contexto, a intersubjetividade (ato de fala manipulativo, agora mais mitigado) se manifesta associada à avaliação do personagem João André quando este manifesta seu descontentamento frente à declaração de Raimundo. 
A meio caminho entre os contextos de advertência e interjetivo, encontramos duas ocorrências de olha, uma em cada século, com aparente sobreposição de significados. É o que se verifica em (8), onde o Cabo, na fala iniciada pelo MD, pode tanto estar advertindo Paulo com relação à sua atitude de tentar se livrar da prisão, como expressando certa surpresa frente à declaração de inocência do preso.

(8) PAULO (forçando para se livrar) - Largue-me, com mil demônios! Já lhe disse que não fui eu!

O CABO (segurando-o sempre) - Olhe, assim agrava a situação!...

COMENDADOR (admirado) - Paulo! (COUTINHO, 2001, p.61).

Prosseguindo, em contextos de atenuação as ocorrências de olha correspondem a cerca de $9 \%$ dos casos tanto na escrita quanto na fala, não se verificando, portanto, diferenças entre as amostras em relação ao uso desse MD nesse tipo de contexto. Nenhuma ocorrência de vê foi encontrada, o que nos leva a hipotetizar que esse pode ser um contexto de restrição a vê. Observe o exemplo (9).

(9) D. MANOEL - Sim, tens razão: o cão que nos lambe a mão também nos tem amizade, e nós o acariciamos; mas nem o cão se eleva a nós, e nem nós baixamos ao cão.

MARIA - tristemente - Meu bom pai, não seja mau! Como pode fazer tal Comparação?!

D. MANOEL - Olha, Maria, perdoo-te porque és mulher, e... és criança. Lembra-te porém sempre de quem descendes: somos de raça que pode quebrar, mas não dobrar; e fica sabendo que proíbo-te toda e qualquer familiaridade com rendeiros, marinheiros e mercadores. São vilões, que, quando têm algumas patacas, esquecem a origem e miram alto. Sinto-me sufocado no meio desta gente, e permita Deus que o vento mude a ver se me vejo livre desta... (CARVALHO, 1994, p.17).

No diálogo em (9), o pai faz uma declaração que estampa na filha um descontentamento. A fim de atenuar sua declaração, o pai, ao retomar o turno, inicia-o com o MD olha. Encontramos ainda, nesse tipo de contexto, marca de intersubjetividade, aliada à avaliação subjetiva na medida em que o F imprime certo abrandamento quanto à declaração anteriormente expressa.

O contexto interjetivo é o segundo mais recorrente na amostra escrita (22\% das ocorrências de MDs nas peças se encontram nesse contexto). É interessante observar que, enquanto no século XIX há 6 ocorrências de olha e nenhuma de vê, no século XX o uso de vê (4 ocorrências) suplanta o de olha (3 ocorrências). Na amostra oral, também se encontram os dois MDs, porém apenas $8 \%$ dos dados de fala (55/709) se concentram nesse tipo de contexto. 
Foi, portanto, nas peças que o uso dos MDs se mostrou mais recorrente em contexto interjetivo.

(10) MEFISTO - Por favor, vou ficar com pena de você e não teremos drama. Não percebeu ainda que não há solução para isto? Não podemos pensar em nada mais amplo, mais coletivo. Meu problema é eu com você, nada mais.

FAUSTO - só quero entender. Mas também não quero, veja só! Isso tudo é muito antigo. Se eu quero entender, volto ao velho Fausto e vou vender minha alma. Se eu não quero saber nada, porque estou no tempo certo da história, não há drama. Devolva os ingressos e as pessoas voltam para suas casas sem muito o que pensar. Se bem que já estão acostumadas. Ah, eu tô confuso! (BRÜGGEMANN, 1999, p.56).

No exemplo (10), além da orientação por parte do F em direção ao O, a depender da entonação, o interlocutor pode inferir outra informação - positiva ou negativa - que expressa a avaliação de F sobre o que é dito.

Os contextos seguintes são de prefaciação e de parentetização, ausentes na amostra escrita e com pouco mais de 5\% (36/709) e de 3\% (23/709), respectivamente, das ocorrências de MDs na fala. No primeiro contexto, 94\% das ocorrências são de olha; já o segundo contexto se revela como o preferencial para vê (65\%) nas entrevistas. Na sequência de exemplos, o primeiro é de prefaciação e o segundo de parentização.

(11) $\mathbf{E}$ : E o que que vocês comiam?

F: Olha, eu [pra] depois que $[<\mathrm{me}<\mathrm{co}>]$ comecei crescer como gente, olha, na casa do meu pai nunca faltou nada. Jardim, o pai [tinha] sempre foi bem, nós sempre tínhamos porco, galinha. Ele tinha até as [caixas] caixas de abelha sempre. $[<$ Bo $>$ nós não] [pra] depois que me conheci como gente, que comecei crescer fome não passamos nunca porque o pai foi que teve sorte, depois que foi morar lá muita foi bem, né?22 (PROJETO VARSUL, 2010).

(12) $\mathbf{E}$ : E como é que ele se tornou pastor assim teve que estudar?

F: F [Aí] aí ele foi aquele dia, ele foi lá e se encontrou se, né? Ele veio de lá mudadinho, mudadinho, mudou. [naquela] [daquela] [daquele] daquele dia em diante ele mudou, ele já chegou mudado. Viu como é que é? [Ele <che>] ele chegou de lá Oh! Ele não lia a Bíblia. Você sabe que essa gente nova assim, eles não gostam muito assim Oh! Ele gostava [de] de baile, carnaval, não tinha um carnaval que ele não fizesse uma fantasia. [Ele] ele desfilava na escola de samba, sabe? Não tinha um carnaval que ele não fizesse uma fantasia. Eu tenho até hoje as fantasias dele ali. E ele voltou de lá mudado, mudado. Ele fumava, não fumou mais. Daquele dia em diante ele não fumou mais. [Ele não foi mais] ele não entrou nem num bar mais. Verdade. Eu fiquei Agora você vê, né? a gente Por isso que

22 Trecho extraído da entrevista n. 01 do corpus do Projeto VARSUL, Chapecó. (PROJETO VARSUL, 2010). 
eu digo: "Deus, o que ele tem pra gente, pra vida da gente, pra pessoa eu acho que, né?" eu acho que ele escolhe decerto a pessoa, né? A pessoa é escolhida, por Deus, né? Esse foi escolhido, porque você vê: ele chegou de lá, aquele dia mesmo ele não deitava sem se ajoelhar [na] assim na beira da cama dele, orar, ler a Bíblia. E ao meio dia assim no almoço e tudo, às vezes os pais precisam $<$ tava > estar dizendo ore ou, né? faça uma oração. Nunca mais ele deixou isso aí, orar [na hora da] antes [de] do almoço, quando senta na mesa. E ter a Bíblia, isso ele fazia, né? direto. Não precisou mais falar nada pra ele fazer. E também dali em diante ele nunca mais deixou assim Era direto [da] [na] para o trabalho e do trabalho pra casa e da casa pra igreja. E a vida [dele é $<i>$ ] dele agora é essa. [...]. ${ }^{23}$ (PROJETO VARSUL, 2010).

Observe que, em (11), o informante retarda a resposta à pergunta do entrevistador. O MD olha introduz a resposta que, no início, parece bastante confusa. Sem responder diretamente a pergunta do entrevistador, o F faz questão de ressaltar que na casa do pai nunca faltara nada, inclusive comida, pois a família criava porcos, galinhas e abelhas. Assim, o entrevistador infere pela resposta sugerida do F que a família consumia os derivados (carnes, ovos e mel) dessa criação. Em (12), o trecho destacado assinala interrupção no seguimento da exposição do F. Nesses dados, os MDs, além de indexar a intersubjetividade, também expressam a subjetividade do F, que procura ou retardar o tópico requerido, ou emitir um comentário parentético.

Os quatro últimos contextos expostos na tabela 3 apresentam traços de caráter relacional/textual, com um grau de subjetivização maior que os anteriores. Em contexto exemplificativo, encontramos apenas um dado de olha na amostra escrita. Por outro lado, na amostra oral, aproximadamente 14\% (99/709) dos MDs estão presentes nesse contexto, mantendo a média de distribuição entre olha (80\%) e vê (20\%) nas entrevistas. Vejamos a ocorrência de escrita.

(13) ELVIRA - (Sentando-se no sofá.) Ter medo de mulheres... Este homem é... MACÁRIO - (Descendo.) É rico, menina, é rico... Lembra-te disto.

ELVIRA - Mas é estúpido!

MACÁRIO - Menina, quem tem dinheiro nunca é estúpido, nem ignorante, nem feio e nem idiota. Olha o Ambrósio. Pensas tu que se o Ambrósio tivesse um par de contos de réis, haviam de chamá-lo maluco, como o chamam agora? Estás enganada. Todos o considerariam como o homem de mais juízo deste mundo e classificariam de filosofia a sua maluquice! (Indo à esquerda alta.) Ambrósio! Oh! Ambrósio!

AMBRÓSIO - (Dentro.) Já vou, patrão.

23 Trecho extraído da entrevista n. 13 do corpus do Projeto VARSUL, Lages. (PROJETO VARSUL, 2010). 
MACÁRIO - (Descendo.) Olha conheci um barão tapado como uma porta. O animal, - animal é o termo, - não abria a boca que não disesse um chorrilho de asneiras... mas era podre de rico... (Indo à esquerda alta.) Oh! Ambrósio! Ambrósio! AMBRÓSIO - (Dentro.) Já vou, patrão! (PIRES, 1999, p.223).

No exemplo (13), o personagem Macário usa o MD olha no início de um trecho em que ele pretender dar um exemplo de pessoa "tapada como uma porta". Nesse caso, o componente intersubjetivo diminui e o componente subjetivo vai ganhando mais proeminência espraiando-se no texto, tendo em vista que o item visa a auxiliar na organização do texto de F.

Somente na amostra de peças relativas ao século XX é que se detecta o primeiro uso do MD vê em contexto de opinião. Seguindo o mesmo padrão de distribuição do contexto exemplificativo, as ocorrências de MDs na fala ficam em torno de 15\% (110/709); mas diferentemente daquele, encontramos 98\% de olha e apenas $2 \%$ de vê em contexto de opinião. Observe o exemplo a seguir.

(14) E: E E o que a senhora acha da língua italiana? A senhora acha assim que ele [o] [o] a prefeitura faz alguma coisa pra que essa língua permaneça viva aqui em Chapecó? O que a senhora acha? Acha bonita a [língua?]

F: [Olha,] [eu acho] é, pra quem entende bem, ela é bonita, né? quem fala bem e quem ouve ela, assim, no caso, né? por exemplo, se tu falares bem, que eu te entendo, né? então eu acho que duas pessoas que se entendem bem, acho que vale a pena, né? É bonito. $[<\mathrm{Co}>]$ porque eu acho que a mesma coisa das pessoas que falam uma outra língua também, né? e é importante, né? no caso se falar mais línguas Mas aqui bem assim, pra te dizer a verdade, eu não sei mesmo [o que que eles] o que que eles estão fazendo com a língua italiana, né? acho que não fazem muita coisa, não. ${ }^{24}$ (PROJETO VARSUL, 2010).

Em (14), o F emprega o MD olha na abertura de um contexto em que é instigado a expor sua opinião sobre a língua italiana, ratificada pelo uso do MD de opinião (eu) acho (que). O MD se localiza em posição relacional marcando a crença/opinião do $\mathrm{F}$.

O contexto que se mostra mais recorrente na amostra oral é o causal, com $23 \%$ das ocorrências (162/709). Esse é também o contexto em que os MDs se distribuem de modo mais equilibrado na amostra oral, com 51\% de olha e 49\% de vê. Na escrita, temos um dado de olha no século XIX e dois de vê no século XX. O contexto causal pode ser bem ilustrado com o exemplo (15), onde o MD coocorre com o conector porque, reforçando o valor relacional do $\mathrm{MD}$, o que torna o componente subjetivo mais atuante, no sentido de que o F procura organizar seu próprio texto.

24 Trecho extraído da entrevista n. 09 do corpus do Projeto VARSUL, Chapecó. (PROJETO VARSUL, 2010). 
(15) $\mathbf{E}$ : Como é que é, como é que consegue conciliar assim do Você é vendedora, né? como é que consegue conciliar, assim, tu tens quatro filhos pra cuidar, né? e mais o trabalho de casa e mais o trabalho de fora. Como é que consegue?

F: Olha, [não é] não é bem fácil, né? porque veja bem, quatro filhos mais o de casa, né? eu acho, assim, que é bem <dificultoso>, sabe? pra mim. Tanto que eu tenho tudo eu tenho horário, sabe?

pra tudo eu tenho horário, né? Então de manhã eu tenho que ficar em casa porque, né? tem que lavar roupa tem que fazer almoço, né? até [mandar] mandar todo mundo pra escola. Então, geralmente eu saio [depois da] de tarde, né? depois que eu acabo o serviço, né? Então foi esse meio que eu achei pra mim ter [o meu] o meu dinheiro, o meu ganho, né? pra ajudar em casa, foi esse. Porque se eu arrumo um serviço no comércio ou um outro tipo de serviço aí, com o grau de estudo que eu tenho, eu vou ganhar pouco, né? pra mim pagar uma empregada, não dá, se eu for tirar pra sair o dia todo de casa, eu tenho que colocar uma empregada porque daí não vou dar conta, as crianças são pequenas, tem que ter alguém pra atender, né? [...].25

Por fim, foram identificadas duas ocorrências de olha em contexto concessivo na fala e nenhuma ocorrência de MD nesse contexto na escrita. Vejamos o exemplo a seguir:

(16) E: E Mas o senhor acha que ele é capaz de ganhar a [eleição?]

F: [Não,] não. [A gente] aí a gente tem que ser honesto com a gente mesmo [ele não] talvez numa próxima, agora ele se lançando como presidente pra ele ser conhecido, nacionalmente, tá? Porque, no Nordeste, eles não conhecem [quem é o] quem é o Espiridião Amin, né? Talvez até São Paulo, tá? e olha lá. Quem é o Espiridião Amin? Eles conhecem agora, porque caracterizam ele, por causa daquela careca, aquele negócio todo, é uma figura que marca. Mas, pra presidente da república, [não] mesmo com [a] toda mídia e com supondo se que a Globo ou a Manchete, todo mundo investisse em cima de Amin, mesmo assim, eu acho que ele não ganha, porque eu acho que esse ano é do Lula e [ninguém] leva, é, eu acho que ninguém leva, é.). (PROJETO VARSUL, 2010).

Nesse contexto, julgamos que e olha lá atua como operador argumentativo, uma vez "que põe em dúvida o argumento que o falante apresentou como válido" (TRAVAGLIA, 2003, p.134). Essa construção frequentemente atua no fechamento do turno desenvolvido pelo F, devolvendo-o ao entrevistador. Em termos de graus de envolvimento de $\mathrm{F}$ e $\mathrm{O}$, o item indexa sutilmente a intersubjetividade, alocando-se no final do enunciado; por outro lado, acentua claramente a avaliação subjetiva do F.

25 Trecho extraído da entrevista n. 11 do corpus do Projeto VARSUL, Blumenau. (PROJETO VARSUL, 2010). 
O mapeamento semântico-pragmático dos itens indica que olha e vê convivem como camadas do domínio da chamada da atenção do ouvinte em sete dos dez contextos de atuação discursiva descritos (com a ressalva de que em contextos de advertência, opinião e prefaciação, o uso de vê é incipiente). Apenas três contextos são de uso exclusivo do MD olha (adversativo, de atenuação e concessivo). Nesse caso, podemos interpretar esses contextos, pelo menos nas amostras analisadas, como de restrição ao uso de vê.

\section{Considerações Finais}

A análise realizada - considerando-se o contexto comunicativo/pragmático em que itens lexicais/gramaticais podem desenvolver polissemicamente novas funções e admitindo-se que o aumento de (inter)subjetividade impulsiona a gramaticalização - evidenciou que:

(i) o MD olha é o item de uso produtivo mais antigo nas peças teatrais; a taxa percentual de seu uso em relação a vê se mantém superior a 80\% em ambas as amostras, escrita e oral;

(ii) quanto à forma dos MDs, olha (IND) se estabeleceu na escrita ao longo do tempo, sendo de uso largamente preferencial na fala; por outro lado, veja (SUBJ) é forma praticamente categórica na escrita e vê (IND) é predominante na fala;

(iii) contextos de uso dos MDs em peças teatrais já no século XIX se mantêm nas entrevistas sociolinguísticas atuais e se expandem significativamente;

(iv) significados de conteúdo evoluem para significados procedurais, passando também a apresentar matizes textuais (mais de 50\% dos dados de MD na fala se distribuem em contextos e posições relacionais, notadamente causal, exemplificativo e de opinião - sendo este último de uso quase exclusivo de olha);

(v) a rotinização de determinado item num certo tipo de contexto pode fazer com que traços do contexto sejam incorporados a ele, de modo que valores contextuais podem passar a ser interpretados como parte do significado do item;

(vi) a ritualização resultante da repetição de uso se reflete tanto na redução fonética e na rigidez formal como na generalização de contextos, indícios de um processo de mudança mais adiantado do MD olha em relação a vê.

Concluímos, portanto, que os MDs olha e vê, resultantes de mudança semântico-pragmática e de mudança categorial verbo $>\mathrm{MD}$, podem ser incluídos no rol de itens que passam por processo de gramaticalização no PB, à semelhança do que ocorre em outras línguas românicas. 
ROST SNICHELOTTO, C. A.; GÖRSKI, E. M. (Inter)subjectivization of verb-derived discourse markers: instances of grammaticalization. Alfa, Araraquara, v.55, n.2, p.423-455, 2011.

- ABSTRACT:This paper presents, in a panchronic view, a description of the multifunctionality of the Brazilian Portuguese discourse markers olha e vê in a written and oral corpus from Santa Catarina State, Brazil. Based on a functionalist approach to grammaticalization, the analysis focuses on the semantic-pragmatic and categorical changes of those markers, and on the concepts of (inter)subjectivity and (inter)subjectification and their relation to the functions of language in the process of change. The analysis shows that (i) pragmatic polysemies emerge from communicative practices and signals, with different degrees, the interpersonal involvement between the speaker and the hearer, an increment of meanings related to the speaker's attitude towards what is said, and an incipient function of the markers on the textual dimension; (ii) the different discourse-function contexts of olha and vê are attested by frequencies of use that point to both variation and constraint contexts; (iii) there are clues to grammaticalization of those markers, in which olha seems to be in a more advanced process than vê.

- KEYWORDS: Discourse markers. Olha and vê. (Inter)subjectivization. Grammaticalization.

\section{REFERÊNCIAS}

BRÜGGEMANN, F. Trilogia da angústia. Sim, eu sei. Prenome: Fausto. Blues \& Souza. Florianópolis: Ed. da UFSC, 1999.

BYBEE, J. Mechanisms of change in grammaticalization: the role of frequency. In: JOSEPH, B. D.; JANDA, J. (Ed.). The handbook of historical linguistic. Oxford: Blackwell, 2003. p.602-623.

CAMARA JUNIOR, J. M. Estrutura da língua portuguesa. 22. ed. Petrópolis: Vozes, 1994.

CARVALHO, A. A. de. Raimundo: drama em cinco atos. Florianópolis: Ed. da UFSC, 1994.

CASTILHO, A. T. de. Para o estudo das unidades discursivas no português falado. In: 1989. p.249-279.

(Org.). Português culto falado no Brasil. Campinas: Ed. da Unicamp,

COUTINHO, J. C. L. Quem desdenha quer comprar. Comédia em um ato. A casa para alugar. Comédia em um ato. Porto Alegre: Movimento, 2001.

CUENCA, M. J.; MARÍN, M. J. Verbos de percepción gramaticalizados como conectores: análisis contrastivo español-catalán. In: MALDONADO, R. Revista Española de Linguística Aplicada, Logroño, p.215-237, 2000.

DOMÍNGUEZ, C. L.; ÁLVAREZ, A. Marcadores en interacción: um estudio de marcadores en el español hablado en Mérida (Venezuela). Revista Virtual de Estudos da Linguagem, [s.l.], v.3, n.4, mar. 2005. Disponível em: <http://www. 
revel.inf.br/site2007/_pdf/4/artigos/revel_4_marcadores_en_interaccion.pdf>. Acesso em: 15 set. 2008.

DOMÍNGUEZ PORTELA, S. Olla e mira, dous marcadores discursivos en tres linguas: portugués, galego e español. Cadernos de Lingua, A Coruña, n.30/31, p.27-73, 2008-2009.

DOSTIE, G. Deux marqueurs discursifs issus de verbes de perception: de "écouter"/ "regarder" à "écoute"/ "regarde". Cahiers de Lexicologie, Paris, n.73, p.85-106, 1998.

GALUÉ, D. Marcadores conversacionales: un análisis pragmático. Boletín de Linguística, Caracas, v.18, p.27-48, 2002.

GIVÓN, T. Syntax: an introduction. Philadelphia: John Benjamins, 2001. 2v.

GÖRSKI, E. M. A questão do continuum na interface variação/gramaticalização. In: MATZENAUER, C. L. B. et al. (Org.). Estudos da linguagem: VII Círculo de Estudos Linguísticos do Sul. Pelotas: EDUCAT, 2008. p.145-172.

GÖRSKI, E. G.; ROST, C. A.; DAL MAGO, D. Aspectos pragmáticos da mudança via gramaticalização. In: CRHISTIANO, M. E. A.; SILVA, C. R.; DA HORA, D. Funcionalismo e gramaticalização: teoria, análise, ensino. João Pessoa: Ideia, 2004. p.29-64.

GUERRA, A. R. Funções textual-interativas dos marcadores discursivos. 2007. $233 f$. Dissertação (Mestrado em Estudos Linguísticos) - Instituto de Biociências, Letras e Ciências Exatas, Universidade Estadual Paulista, São José do Rio Preto, 2007.

HALLIDAY, M. A. K.; HASAN, R. Cohesion in English. London: Longman, 1976.

HEINE, B.; CLAUDI, U.; HÜNNEMEYER, F. From cognition to grammar - evidences from African languages. In: TRAUGOTT, E.; HEINE, B. (Ed.). Approaches to grammaticalization. Philadelphia: John Benjamins, 1991. v.1. p.149-187.

HEINE, B.; KUTEVA, T. The genesis of Grammar. a reconstruction. New York: Oxford University Press, 2007.

HOPPER, P. On some principles in the grammaticalization. In: TRAUGOTT, E.; HEINE, B. (Ed.). Approaches to grammaticalization. Philadelphia: John Benjamins, 1991. v.1. p.17-35.

Emergent grammar. In: ANNUAL MEETING BERKELEY LINGUISTICS SOCIETY, 13., 1987, Berkeley. Papers... Berkeley: Berkeley Linguistic Society, 1987. p.139-157.

HOPPER, P.; TRAUGOTT, E. Grammaticalization. Cambridge: Cambridge University Press, 2003. 
JUBRAN, C. C. A. S. Parentetização. JUBRAN, C. C. A. S.; KOCH, I. G. V. (Org.). Gramática do português culto falado no Brasil. Campinas: Ed. da Unicamp, 2006. v.1. p.301-358. (Construção do texto falado).

JUVENAL, I. Obras completas. Teatro. Florianópolis, 1942. v.1. p.74-121.

LABOV,W. Principles of linguistic change: internal factors. Oxford: Blackwell, 1994.

LONGHIN-THOMAZI, S. Um exemplo de (inter)subjetivização na linguagem: a reconstrução histórica de 'ainda'. Estudos Linguísticos, Campinas, v.1, n.35, p.772-1779, 2006.

A gramaticalização da perífrase conjuncional "só que". 2003. 212f. Tese (Doutorado em Linguística) - Instituto de Estudos da Linguagem, Universidade Estadual de Campinas, Campinas, 2003.

LOPES-DAMASIO, L. R. A emergência do marcador discursivo assim sob a ótica da gramaticalização: um caso de multifuncionalidade e (inter)subjetivização. 2008. 244f. Dissertação (Mestrado em Estudos Linguísticos) - Instituto de Biociências, Letras e Ciências Exatas de São José do Rio Preto, Universidade Estadual Paulista, São José do Rio Preto, 2008.

LOREGIAN-PENKAL, L. (Re)análise da referência de segunda pessoa na fala da região Sul. 2004. 261 f. Tese (Doutorado em Letras) - Setor de Ciências Humanas, Letras e Artes, Universidade Federal do Paraná, Curitiba, 2004.

MARCUSCHI, L. A. Marcadores conversacionais do português brasileiro: formas, funções e definições. In: CASTILHO, A. (Org.). Português culto falado no Brasil. Campinas: Ed. da UNICAMP, 1989. p.281-322.

MARÍN JORDÀ, M. J. Discurs i gramaticalització: verbs de percepció usats com a marcadors discursius en el debat electoral. 2003. 686 f. Tese (Doutorado em Filologia) - Departament de Filologia Catalana, Universitat de València, València, 2003.

MARTELOTTA, M. Marcadores discursivos e operadores argumentativos. In: VOTRE, S.; MARTELOTTA, M. E. (Org.). Trajetórias de gramaticalização e discursivização. Rio de Janeiro: Tempo Brasileiro, 1998. p.64-93.

MARTELOTTA, M.; VOTRE, S.; CEZARIO, M. M. (Org.). Gramaticalização no português do Brasil: uma abordagem funcional. Rio de Janeiro:Tempo Brasileiro, 1996.

MATZENAUER, C. L. B. et al. (Org.). Estudos da linguagem:VII Círculo de Estudos Linguísticos do Sul. Pelotas: EDUCAT, 2008. 
PAIVA, M. C. Ordenação das cláusulas causais: forma e função. 1992. 232f. Tese (Doutorado em Linguística) - Faculdade de Letras, Universidade Federal do Rio de Janeiro, Rio de Janeiro, 1992.

PAULA, N. G. de. Uma longa história de amor. In: 13 textos para teatro: dramaturgia do oeste catarinense. Chapecó, 1999.

PIRES, H. N. O idiota. In: JUNKES, L. (Org.). Teatro selecionado. Florianópolis: Ed. da UFSC, 1999. p.217-252.

PONS BORDERÍA, S. Oye y mira o los límites de la conexión. In: ZORRAQUINO, M. A. M. et al. (Ed.). Los marcadores del discurso: teoría y análisis. Madrid:Arco Libros, 1998. p.213-228.

PROJETO VARSUL. Variação Linguística na Região Sul do Brasil: banco de dados. Disponível em: < http://www.varsul.org.br/?modulo=secao\&id=1/>. Acesso em: 08 ago. 2010.

RISSO, M. S. Marcadores discursivos basicamente sequenciadores. In: JUBRAN, C. C. A. S; KOCH, I. G. V. (Org.). Gramática do português culto falado no Brasil. Campinas: Ed. da Unicamp, 2006. v. 1. p.427-496. (Construção do texto falado).

Aspectos textuais-interativos dos marcadores discursivos de abertura Bom, Bem, Olha, Ah, no português culto falado. In: NEVES, M. H. M. (Org.). Gramática do português falado. Campinas: Ed. da Unicamp, 1999. v.7.

RISSO, M. S.; SILVA, G. M. O.; URBANO, H. Marcadores discursivos basicamente sequenciadores. In: JUBRAN, C. C. A. S; KOCH, I. G. V. (Org.). Gramática do português culto falado no Brasil. Campinas: Ed. da Unicamp, 2006. v.1. p.427-496. (Construção do texto falado).

Marcadores discursivos: traços definidores. In: KOCH, I. G. V. (Org.). Gramática do português falado. Campinas: Ed. da Unicamp, 1996. v.4. p.21-94.

ROST, C. A. Olha e veja: multifuncionalidade e variação. 2002. 158f. Dissertação (Mestrado em Linguística) - Centro de Comunicação e Expressão, Universidade Federal de Santa Catarina, Florianópolis, 2002.

ROST SNICHELOTTO, C. A. 2009. 411f. Olha e vê: caminhos que se entrecruzam. 2009. Tese (Doutorado em Linguística) - Centro de Comunicação e Expressão, Universidade Federal de Santa Catarina, Florianópolis, 2009.

SCHIFFRIN, D. Discourse markers. Cambridge: Cambridge University Press, 1987.

SILVA, G. M.; MACEDO, A. Análise sociolinguística de alguns marcadores conversacionais. In: MACEDO, A.; RONCARATI, C.; MOLLICA, M. C. (Org.). Variação e discurso. Rio de Janeiro: Tempo Brasileiro, 1996. p.11-50. 
SILVA JÚNIOR, J. D. Em tua homenagem ou não. In: BELTRAME, V.; GIOSO, S.; ESPEZIM, C. A. Dramaturgia: III Concurso Estadual 1983. Florianópolis: Fundação Catarinense de Cultura, 1984.

TRAUGOTT, E. C. (Inter)subjectivivity and intersubjectification: a reassessment. In: CUYCKENS, H.; DAVIDSE, K.; VANDELANOTTE, L. (Ed.). Subjectification, intersubjectification and grammaticalization. Berlin: Walter de Gruyter, 2010. p.29-71. (Topics in English Linguistics, 66).

. Constructions in grammaticalization. In: JOSEPH, B. D.; JANDA, J. (Ed.). The handbook of historical linguistic. Oxford: Blackwell, 2003a. p.624-647.

. From subjectification to intersubjectification. In: HICKEY, Raymond (Ed.). Motives for language change. Cambridge, U.K.: Cambridge University Press, 2003b. p.124-139.

. From etymology to historical pragmatics. In: MINKOVA, D.; STOCKWELL, R. (Ed.). Studying the History of the English Language: millennial perspectives. Berlin: Mouton de Gruyter, 2002. p.19-49.

The role of the development of discourse markers in a theory of grammaticalization. In: INTERNATIONAL CONFERENCE ON HISTORICAL LINGUISTICS, 12., Manchester, 1995. Proceedings... Manchester: [s.n.], 1995.

. On the rise of epistemic meanings in English: an example of subjectification in semantic change. Language, Washington, v.65, n.1, p.31-55, 1989.

. From propositional to textual and expressive meanings: some semanticpragmatic aspects of grammaticalization. In: LEHMMAN,W. P.; MALKIEL,Y. (Org.). Perspectives on Historical Linguistics. Amsterdam: Benjamins, 1982. p.245-271.

TRAUGOTT, E. C.; DASHER, R. B. Regularity in semantic change. Cambridge: Cambridge University Press, 2002.

TRAUGOTT, E. C. HEINE, B. (Ed.). Approaches to grammaticalization. Philadelphia: John Benjamins, 1991. 2v.

TRAUGOTT, E. C.; KÖNIG, E. The semantics-pragmatics of grammaticalization revisited. In:TRAUGOTT, E. C.; HEINE, B. (Ed.). Approaches to grammaticalization. Philadelphia: John Benjamins, 1991. v.1, p.189-218.

TRAVAGLIA, L. C. Verbos gramaticais: verbos em processo de gramaticalização In: FIGUEIREDO, C. A. et al. (Org.). Lingua(gem): reflexões e perspectivas. Uberlândia: Ed. da UFU, 2003. p.97-157.

. O relevo no português falado: tipos e estratégias, processos e recursos. In: NEVES, M. H. M. Gramática do português falado: novos estudos. São Paulo: Humanitas, 1999. v.7. p.77-130. 
URBANO, H. Marcadores discursivos basicamente interacionais. In: JUBRAN, C. C. A. S; KOCH, I. G. V. (Org.). Gramática do português culto falado no Brasil. Campinas: Ed. da Unicamp, 2006. v.1. p.497-528. (Construção do texto falado).

Aspectos basicamente interacionais dos marcadores discursivos. In: NEVES, M. H. M. (Org.). Gramática do português falado. Campinas: Ed. da Unicamp, 1999. v.7. p.195-258.

Marcadores conversacionais. In: PRETI, D. (Org.). Análise de textos orais. 3. ed. São Paulo: Humanitas, 1997. v.1. p.81-101.

WALTEREIT, R. Imperatives, interruption in conversation, and the rise of discourse markers: a study of Italian guarda. Linguistics, Berlin, v.40, n.5, p.987-1010, 2002.

Recebido em março de 2011.

Aprovado em abril de 2011. 